\begin{tabular}{|l|l|l|}
\hline \multicolumn{2}{|c|}{ PublisherInfo } \\
\hline \hline PublisherName & $:$ & BioMed Central \\
\hline \hline PublisherLocation & $:$ & London \\
\hline \hline PublisherImprintName & $:$ & BioMed Central \\
\hline \hline
\end{tabular}

\title{
Making sense of antisense
}

\begin{tabular}{|l|l|l||}
\hline \multicolumn{2}{|c|}{ ArticleInfo } \\
\hline \hline ArticleID & $:$ & 4181 \\
\hline \hline ArticleDOI & $:$ & $10.1186 /$ gb-spotlight-20010820-01 \\
\hline \hline ArticleCitationID & $:$ & spotlight-20010820-01 \\
\hline \hline ArticleSequenceNumber & $:$ & 252 \\
\hline \hline ArticleCategory & $:$ & Research news \\
\hline ArticleFirstPage & $:$ & 1 \\
\hline \hline ArticleLastPage & $:$ & 2 \\
\hline \hline & & RegistrationDate : 2001-08-20 \\
ArticleHistory & $:$ & OnlineDate $\quad$ 2001-08-20 \\
\hline \hline ArticleCopyright & $:$ & BioMed Central Ltd2001 \\
\hline \hline ArticleGrants & $:$ & \\
\hline \hline ArticleContext & $:$ & 130592211 \\
\hline \hline
\end{tabular}




\section{Jonathan B Weitzman}

Email: jonathanweitzman@hotmail.com

The specificity of antisense approaches is much debated and has hampered their development for clinical therapeutics. In the August 14 Proceedings of the National Academy of Sciences, Yee Cho and colleagues at the National Institutes of Health, Bethesda, MD, report the use of DNA microarrays to resolve aspects of the mechanism of antisense action (Proc Natl Acad Sci USA 2001, 98:9819-9823). They investigated the effects of antisense oligonucleotides targeting the regulatory RI $\alpha$ subunit of cAMP-dependent protein kinase (PKA). They treated human PC3 prostate cancer cells with antisense phosphorothioate oligonucleotides (PS-ODNs) or with 2'-O-methyl RNA/DNA hybridODNs and examined changes in the expression profiles of over 2,300 genes. Expression of about $10 \%$ of the genes was altered by antisense treatment. The results were very similar whether exogenous ODNs or endogenous antisense gene overexpression were used. RI $\alpha$ antisense treatment affected a specific subset of genes, causing decreased expression of proliferation-related gene clusters, and boosted the expression of differentiation-related genes. Defining gene expression profiles upon antisense treatment may help to answer some of the concerns about ODN-directed antisense strategies in the clinic.

\section{References}

1. Potential roles of antisense technology in cancer chemotherapy.

2. Proceedings of the National Academy of Sciences, [http://www.pnas.org]

3. National Institutes of Health, [http://www.nih.gov]

4. The cAMP-dependent protein kinases and cAMP signal transduction.

5. Oligonucleotide sequence-specific inhibition of gene expression, tumor growth inhibition, and modulation of cAMP signaling by an RNA-DNA hybrid antisense targeted to protein kinase A RIalpha subunit.

This PDF file was created after publication. 